\title{
Gall bladder sludge and stones in multitransfused Egyptian thalassaemic patients
}

\section{A. El-Nawawy, ${ }^{1}$ A.S. Kassem, ${ }^{1}$ M. Eissa, ${ }^{\prime}$ M. Abdel-Fattah' and M. Safwat ${ }^{1}$}

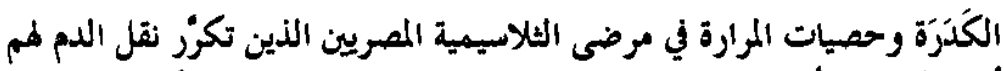

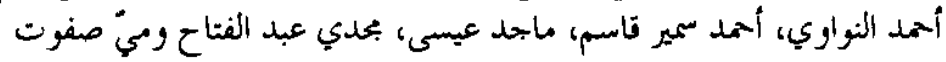

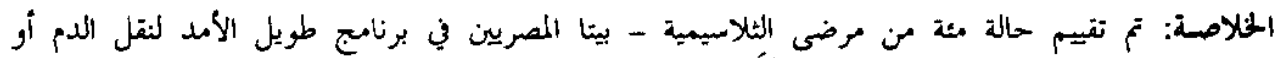

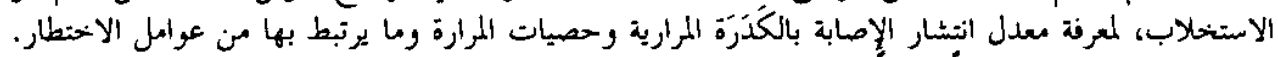

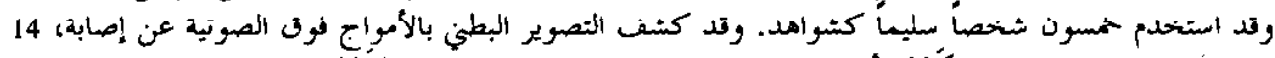

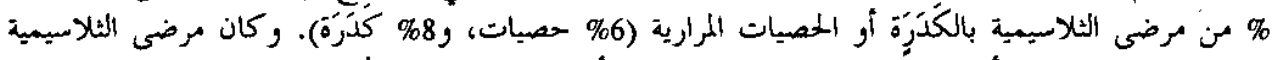

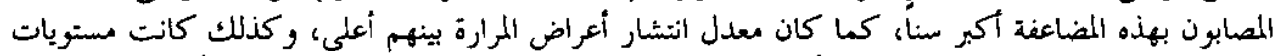

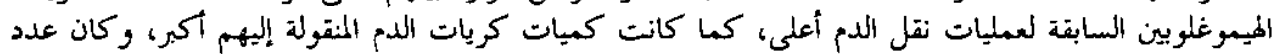

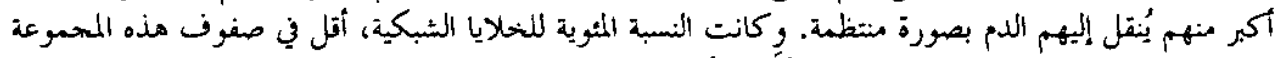

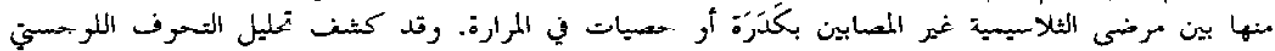

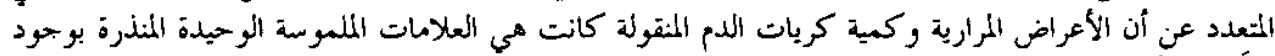

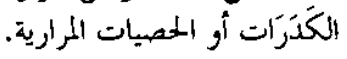

ABSTRACT One hundred Egyptian $\beta$-thalassaemic patients on a long-term transfusion/chelation programme were evaluated for the prevalence of gall balder sludge and stones and the associated risk factors. Fitty hoalthy individuals served as controls. Abdominal ultrasonography revealed that $14 \%$ of the thalassaemic patients had gall bladder sludge or stones (6\% stones and $8 \%$ sludge). The thalassaemic patients with this complication were older, had a higher prevalence of gall bladder symptoms, higher leveis of pretransfusion haemoglobin, larger amounts of transfused red cells, and more were regularly transfused. Multiple logistic regression analysis revealed that the presence that gall bladder symptoms and the amount of transfused red cells were the only significant predictors of the occurrence of gall bladder sludge or stones.

Boues et calculs biliaires chez des patients thałassemiques egyptiens polytranstuses

RESUME Cent patients $\beta$-thalassémiques égyptiens inclus dans un programme de transfusion/chélation à long terme ont fait l'objet d'une évaluation en ce qui concerne la prévalence des boues et calculs biliaires et les facteurs de risques associés. Cinquante sujets en bonne santé servaient de témoins. L'échographie abdominale a révélé que $14 \%$ des patients thalassémiques avaient des boues ou des calculs biliaires $6 \%$ pour les calculs et $8 \%$ pour les boues). Les patients thalassémiques ayant cette complication étaient plus âdés. avaient une prévalence plus élevée de symptômes de la vésicule biliaire. des taux plus élevés d'hémoglobine avant la transfusion, des quantités plus grandes de globules rouges transfusés, et un plus grand nombre de ces patients étaient transfusés régulièrement. Lanalyse de régression logistique multiple a révélé que la présence de symptômes de la vésiculaire biliaire et la quantité de globules rouges transfusés étaient les seuls facteurs prédictifs de l'apparition de boues ou de calculs biliaires.

Department of Paediatrics, Faculty of Medicine. University of Alexandria. Alexandria. Egyot. Received: 04/07/00; accepted: 07/01/01

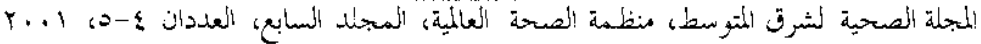




\section{Introduction}

The thalassacmias are a heterogencous group of heritable hypochromic anaemias of various degrees of severity. Thalassacmia genes are remarkably widespreat, and thalassaemias are believed to be the most prevalent of all human genetic diseascs [l]. The World IIcalth Organization (WHO) has conservatively estimated that $7 \%$ of the world's population will be carricrs by the year 2000 , most of them in the tropics [2]. Beta-thalassaemia is one of the commonest forms of thalassaemias.

The striking improvement in life cxpectancy of patients with homozygous $\beta$ thalassaemia observed over the past three decades is mainly due to the institution of adequate transfusion regimens and effective iron chelation with subcutaneous desferrioxamine [3]. The prevalenee of severe complications, however, remains high [4].

The occurrence of pigmentary cholelithiasis in $\beta$-thalassaemic patients is not uncommon, although its incidence has not yet been precisely determined [5]. In recent years it has been shown that 20\% of all gallstones are due to recurring haemolysis [6]. Pigmented stones, composed of calcium bilirubinate, may be found as early as the fourth year of life [7].

Biliary sludge, "a viscid bile", is an ultrasonographic observation which usually causes low-level echoes in the dependent portion of the gall bladder. It varies with posture and, unlike gallstones, caste no acoustic shadow [8]. Persisting sludge can be a predisposing factor for cholelithiasis and cholecystitis. In a prospective ultrasonographic study of $\beta$-thalassaemic patients, cholelithiasis was found in $8.4 \%$ of patients, while biliary sludge was detected in $34.6 \%$ [9].

We aimed to examine gall bladder sludge and stones in a group of Egyptian thalas- saemic patients on long-term transfusion/ chelation programmes and to evaluate clinical and laboratory findings, including transfusion history, reticulocyte count and use of chelation therapy, as predictors for gall bladder sludge or stones.

\section{Methods}

Included in the study were $100 \beta$-thalassaemic patients (mean age $18.4 \pm 4.6$ years) on long-term transfusion/chelation programmes, who regularly attended the haematology/oncology clinic of the Iniversity of Alexandria Children's Hospital. As controls, 50 healthy sex- and age-matched subjects (mean age $16.6 \pm 2.9$ years) were recruited. Informed consent was obtained from all the parents and/or participants, whichever was appropriate. and the study was approved by the Ethics Committee of the University of Alexandria.

A thorough history was taken from all participants, with emphasis on gall bladder symptoms (recurrent upper quadrant or epigastric pain, typical biliary colic. nonspecific dyspepsia, fatty food intolerance and occasional nausea and vomiting); previous infectious diseases such as mumps. measles and chicken pox; previous attacks of jaundice; and history of splenectomy if performed. All details of the transfusion/ chelation programme were obtained from the patient's medical records.

A morning venous blood sample was obtained from all participants (pretransfusion in thalassaemic patients) to estimate haemoglobin ( $\mathrm{Hb}$ ) level, serum bilirubin (total and direct), reticulocyte count, total white cell count and percentage of neutrophils, serum cholesterol and serum calcium concentrations.

All participants underwent abdominal ultrasonography with a conventional digital 
grey scale scanner (Aloka SSD-630) using a linear $5 \mathrm{MHz}$ transducer. Participants were prepared by a 12-hour overnight fast prior to sonography to avoid contraction of the gall bladder. The gall bladder was carefully studied in longitudinal and transverse planes for the presence of sludge or stones.

Statistical analysis was done using SSPS, version 6. Statistical tests included Fisher exact test, Student $t$-test, Pearson correlation and multiple logistic regression analysis for predicting risk factors. Statistical significance was defined as $P<0.05$.

\section{Results}

Table 1 presents the clinical, laboratory and ultrasonographic data of the thalassaemic patients and controls. Fourteen thalassaemic patients had gall bladder sludge or stones (8 sludge and 6 stones). The mean age of these thalassaemic patients was significantly higher than the other thalassaemic patients. The weight and height percentage from the 50th centile for age and sex were significantly lower in both thalassaemic groups compared to controls. No significant difference was found between the thalassaemic groups in the frequency of splenectomy.

A history of gall bladder symptoms was significantly more common $(28.6 \%)$ in thalassaemic patients with gall bladder sludge or stones compared to other thalassaemic patients $(2.3 \%)$ and controls $(4.0 \%)$. The liver span in centimetres, total and direct serum bilirubin and serum cholesterol concentrations showed no statistically significant difference between the thalassaemic groups but were significantly higher than in the controls, except for serum cholesterol which was significantly lower. The serum calcium, total white cell count and percentage of neutrophils showed no significant differences between the three groups. The pretransfusion haemoglobin concentration in thalassaemic patients with gall bladder sludge or stones was significantly higher than in the other thalassacmic patients, while both groups had significantly lower values than controls. The reticulocyte percentage in the thalassacmic group without gall bladder sludge or stones was significantly higher than in the other two groups, but there was no significant difference between controls and the thalassaemic patients with gall bladder sludge or stones.

Table 2 presents the transfusion/ehelation parameters of both thalassaemic groups. Patients with gall bladder sludge or stones had significantly more packed cells transfusions per year and all were regularly transfused. There were no differences between the two groups in the mean desferrioxamine dosage received or the regularity of chelation treatment. Correlation studies revealed that the amount of desferrioxamine $(\mathrm{g} / \mathrm{kg} /$ year $)$ and the packed cells volume transfused $(\mathrm{mL} / \mathrm{kg} /$ year) correlated positively with the pretransfusion $\mathrm{Hb}$ concentration and negatively with reticulocyte percentage in all thalassaemic patients $\left(r^{2}=\right.$ $0.568,0.871$ and $-0.451,-0.756$ respectively). Multiple logistic regression analysis, including all clinical, laboratory, therapeutic and sonographic data, revealed that history of gall bladder symptoms and mean volume of packed red cells transfused $(\mathrm{mL} / \mathrm{kg} /$ year) were the only positive factors that predicted subsequent development of gall bladder sludge or stones among the thalassaemic patients.

\section{Discussion}

In this study the prevalence of gall stone was $6 \%$ and gall bladder sludge was $8 \%$ in 
Table 1 Comparison of the clinical, laboratory and ultrasonography characteristics of thalassaemic patients with and without gall bladder sludge or stones and controls

\begin{tabular}{|c|c|c|c|c|}
\hline Characteristics & $\begin{array}{l}\text { Patients with } \\
\text { gall bladder } \\
\text { sludge or stones } \\
(n=14)\end{array}$ & $\begin{array}{l}\text { Patients without } \\
\text { gall bladder } \\
\text { sludge or stones } \\
(n=86)\end{array}$ & $\begin{array}{l}\text { Controls } \\
(n=50)\end{array}$ & Statistical test \\
\hline Male [No. $(\%)]$ & $6(42.9)$ & $34(39.5)$ & $20(40.0)$ & $\chi_{2}^{2}=0.055$ \\
\hline Female [No (\%)] & $8(57.1)$ & $52(60.5)$ & $30(60.0)$ & $x_{2}^{2}=0.055$ \\
\hline Age (mean $\pm s$ ) (years) & $18.43 \pm 4.65^{a, b}$ & $14.86 \pm 3.89^{\mathrm{b}}$ & $16.60 \pm 2.90$ & $F=7.726^{*}$ \\
\hline $\begin{array}{l}\text { Weight (mean } \pm s) \\
\text { (\% from } 50 \text { th centile) }\end{array}$ & $00.02 \pm 9.73^{\mathrm{h}}$ & $05.30 \pm 9.30^{h}$ & $107.83 \pm 8.61$ & $F=115.21^{*}$ \\
\hline $\begin{array}{l}\text { Height (mean } \pm 5 \text { ) } \\
\text { ( } \% \text { from } 50 \text { th centile) }\end{array}$ & $93.99 \pm 3.27^{\mathrm{b}}$ & $93.19 \pm 3.69^{b}$ & $97.19 \pm 2.44$ & $F=23.02^{*}$ \\
\hline Splenectomy [No. (\%)] & $6(42.9)$ & $32(3 / .2)$ & - & $\chi_{1}^{2}=0.163$ \\
\hline $\begin{array}{l}\text { Gall bladder symptoms } \\
\text { [No. (\%)] }\end{array}$ & $4(28.6)$ & $2(2.3)$ & $2(4.0)$ & $\chi_{2}^{2}=16.69^{*}$ \\
\hline Sludge $[$ No. $(\%)]$ & $8(57,1)$ & - & - & - \\
\hline Stones [No. (\%)] & $6(42.9)$ & - & - & - \\
\hline $\begin{array}{l}\text { Liver span } \\
\qquad(\text { mean } \pm s)(\mathrm{cm})\end{array}$ & $12.29 \pm 2.63^{b}$ & $11.10 \pm 2.03^{b}$ & $8.21 \pm 0.74$ & $F=42.432^{*}$ \\
\hline $\begin{array}{l}\text { Total bilirubin } \\
\qquad(\text { mean } \pm \text { s) }(\mathrm{mg} / \mathrm{dL})\end{array}$ & $1.50 \pm 0.47^{\mathrm{b}}$ & $1.64 \pm 0.60^{\circ}$ & $0.73 \pm 0.15$ & $F=61.79^{\star}$ \\
\hline $\begin{array}{l}\text { Direct bilirubin } \\
\qquad(\text { mean } \pm s)(m g / d L)\end{array}$ & $0.33 \pm 0.12^{\mathrm{b}}$ & $0.49 \pm 0.31^{\mathrm{D}}$ & $0.11 \pm 0.07$ & $F=39.38^{*}$ \\
\hline $\begin{array}{l}\text { Haomoglobin } \\
\qquad(\text { mean } \pm s)(g / d L)\end{array}$ & $9.87 \pm 0.87^{a . b}$ & $8.72 \pm 1.25^{b}$ & $13.26 \pm 0.68$ & $F=293.96^{*}$ \\
\hline $\begin{array}{l}\text { Reticulocytes } \\
(\text { mean } \pm \text { \&) }(\%)\end{array}$ & $1.86 \pm 0.38$ & $2.68 \pm 1.01^{b}$ & $1.36 \pm 0.38$ & $F=43.83^{*}$ \\
\hline $\begin{array}{l}\text { White blood cells } \\
\qquad(\text { mean } \pm \mathrm{s})\left(\mathrm{mm}^{3}\right)\end{array}$ & $11.23 \pm 4.53$ & $11.54 \pm 3.99$ & $11.83 \pm 5.11$ & $F=0.127$ \\
\hline $\begin{array}{l}\text { Neutrophils } \\
\qquad(\text { mean } \pm s)(\%)\end{array}$ & $53.14 \pm 9.70$ & $50.67 \pm 8.70$ & $53.28 \pm 9.35$ & $F=1.539$ \\
\hline $\begin{array}{l}\text { Calcium } \\
\qquad(\text { mean } \pm s)(m g / d L)\end{array}$ & $0.31 \pm 0.44$ & $9.38 \pm 0.59^{b}$ & $9.70 \pm 0.54$ & $F=5.99^{+}$ \\
\hline $\begin{array}{l}\text { Cholesterol } \\
\qquad(\text { mean } \pm \mathrm{s})(\mathrm{mg} / \mathrm{dL})\end{array}$ & $117.57 \pm 6.37^{\circ}$ & $112.12 \pm 6.11^{b}$ & $159.36 \pm 13.23$ & $F=432.89^{\star}$ \\
\hline
\end{tabular}

*Significant at $\mathrm{P}<0.05$.

'Significantly different from cases without gall bladder sludge or stones.

Significantly different from controls.

s = standard deviation. 
Table 2 Transfusion chelation parameters of thalassaemic patients with and without gall bladder sludge or stones

\begin{tabular}{lccc}
\hline $\begin{array}{l}\text { Transfusion } \\
\text { parameter }\end{array}$ & $\begin{array}{c}\text { Patients with } \\
\text { gall bladder } \\
\text { sludge or stones } \\
(n=14)\end{array}$ & $\begin{array}{c}\text { Patients without } \\
\text { gall bladder } \\
\text { sludge or stones } \\
(n=86)\end{array}$ & Statistical test \\
\hline $\begin{array}{c}\text { Mean packed cells } \\
\text { (mean } \pm \text { s) (mL/kg/year) }\end{array}$ & $216.43 \pm 25.77$ & $164.65 \pm 47.38$ & $t=4.102^{*}$ \\
$\begin{array}{l}\text { Regular transfusion } \\
{[\text { No. }(\%)]}\end{array}$ & $14(100)$ & $48(55.89)$ & $\chi_{1}^{2}=10.469^{*}$ \\
$\begin{array}{l}\text { Mean desferrioxamine } \\
\text { (mean } \pm s) \text { (g/kg/year) }\end{array}$ & $2.86 \pm 1.47$ & $2.28 \pm 1.12$ & $t=1.422$ \\
$\begin{array}{c}\text { Regular chelation } \\
{[\text { No. }(\%)]}\end{array}$ & $8(57.1)$ & $26(30.2)$ & $\chi_{1}^{2}=3.885^{*}$ \\
\hline
\end{tabular}

*Significant at $\mathrm{P}<0.05$.

F = standard doviation.

patients with $\beta$-thalassaemia, an overall prevalence of $14 \%$. The reported preva lence from other areas has shown wide variations. In India, a study on multitransfused children with thalassaemia major (aged 5-20 years) showed that none had gall stones on sonography [10], while another prospective ultrasonographic study in Turkey showed cholelithiasis in $8.4 \%$ of patients studied and sludge in 34.9\% [9]. This indicates that the real incidence has not yet been clarified, and there might be differences between ethnic groups.

The mean age of the thalassaemic patients with sludge and stones was significantly higher than that of the other thalassaemic patients. Studies have shown that the incidence of cholelithiasis increases with age in $\beta$-thalassaemic patients [11] and other chronic haemolytic anaemias such as sickle-cell anaemia [12]. This probably reflects the burden of long-term transfusion with the complication of calcium bilirubinate deposits.

We found a higher prevalence of gall bladder symptoms $(28.6 \%)$ in the patients with sludge or stones compared to the other thalassaemic group $(2.3 \%)$. In adults, gallstones may remain asymptomatic for years [13]. A study of sickle-cell disease in Jamaica showed that none of the patients with biliary sludge had any symptoms related to the biliary tract [14].

The mean pretransfusion $\mathrm{Hb}$ concentration was higher in patients with sludge or stones. This is due to the fact that the mean volume of packed red cells transfused was significantly higher. So gall bladder sludge or stones could be classified as a complication of the therapeutic hypertransfusion programme of $\beta$-thalassaemia. The mean concentrations of serum total and direct bilirubin in the thalassaemic groups were higher than in the controls, but a comparison of the two thalassaemic groups showed no statistically significant differences. It should be mentioned that indirect bilirubin is the major agent in bile pigment stone formation. It has been shown that biliary indirect bilirubin may result from increased enzymatic hydrolysis of direct bilirubin (by $\beta$-glucuronidase) in bile or re-

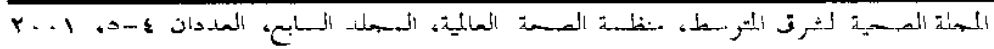


duced amounts of an inhibitor of $\beta$-glucuronidase, glutamic acid [15]. It has also been shown that, in patients with spontaneous haemolysis of endogenous origin, no more than $3 \%$ of total biliary bilirubin is indirect. This explains why the amount of indirect bilirubin resulting from exogenous haemolysed red cells is greater in bile than in serum, due to excess hydrolysis of direct bilirubin. So, the more thalassaemic patients are transfused, the more likely they are to develop pigment stone formation. It should be noted that bilirubin should be precipitated in the form of calcium bilirubinate.

No differences were found between the thalassaemic patients and controls in levels of serum calcium. But in a cirrhotic liver there is a reduction in calcium binders such as the micellar bile salt [15]. This could also be the case in our study, where hepatomegaly is prominent in thalassaemic patients with progressive engorgement of parenchymal and phagocytic cells [16], iron deposition [17] and ultimately fibrosis. Episodes of subclinical hepatitis may contribute to the development of fibrosis and cirrhosis $[18,19]$. Moreover, the increased prevalence of gall stones as a result of the reduction of bile acid concentration that occurs in cirrhosis did not occur in our patients, because the cholesterol:bile acid ratio remained within the normal range, since both our study and other reports [20] indicate that markedly reduced cholesterol levels are characteristic of thalassaemic patients. So the cholesterol:bile acid ratio is not the cause of sludge or stones in the present study: calcium bilirubinate deposition remains the major cause.

The mean reticulocyte percentage was significantly lower $(1.86 \%)$ in the patients with sludge or stones compared to other thalassaemic patients $(2.7 \%)$, indicating an incomplete suppression of erythropoiesis in both groups but a significantly stronger suppression in the patients with gall bladder sludge or stones. This is due to the fact that the latter group had experienced more regular transfusion and had more packed red cells transfused. The reticulocyte count did not reach the normal level because the transfusion programme used is still not completely satisfactory.

The multiple regression analysis study performed included all studied factors. It revealed that only two factors were significant in predicting the acquisition of gall bladder sludge and/or stones: the presence of gall bladder symptoms and the mean volume of packed cells transfused per year.

In conclusion, the longer the survival and better management of patients with âthalassaemia, the more prevalent is the problem of gall bladder sludge and stones. Although most reports indicate that the incidence is still low, we suggest that proper follow-up of thalassaemic patients with abdominal ultrasonography at regular intervals and whenever gall bladder symptoms are suspected should become mandatory. In the meantime, we suggest improving the transfusion/chelation programme with protocols designed to lower the incidence of this complication.

\section{References}

1. Honig GR. Hemoglobin disorders. In: Benrman $\mathrm{HE}$, Kliegman RM, Jensen $\mathrm{HB}$, eds. Nelson textbook of pediatrics, 16 th ed. Philadelphia, WB Saunders Company, 2000:1484-7.

2. Clegg JB. Thalassemia and malaria. Medicine digest. 1990. 16:13-7. 
3. Giardini C. Treatment of beta-thalassemia. Current opinion in hematology, 1997, 4(2):79-87

4. Borgna-Pignatti $\mathrm{C}$ et al. Survival and disease complications in thalassemia major. Annals of the New York Aoadomy of Science, 1998, 850:227-31.

5. Frempong KO, Schwatz E. Clinical features of thalassemla. Peolarric cilnics of North America, 1980, 27:403-19.

6. Holcomb Jr GW, Holcomb 3rd GW. Cholelithiasis in infants, children, and adolescents. Pediatrics in review, 1990, 11(9):268-74.

7. Segel GB. Definitions and classifications of hemolytic anemias. In: Behrman RE, Kliegman RM, Jensen HB, eds. Nelson textbook of pediatrics, 16th ed. Philadelphia, WB Saunders Company, 2000:1472-5.

8. Paumgartner $\mathrm{G}$, Sauerbruch T. Gallstones: pathogenesis. Lancet, 1991, 338:1117-21.

9. Senaati $S$ et al. Gallbladder pathology in pediatric beta-thalassaemic patients. A prospective ultrasonographic study. $\mathrm{Pe}$ diatric radiology, 1993, 23(5):357-9.

10. Chawla $Y$ et al. Multitranstused children with thalassemia major do not have gallstones. Tropical gastroenterology, 1997, 18(3):107-8

11. Goldfarb $A$ et al. High incidenco of cholelithiasis in older patients with homozygous beta-thalassemia. Acta haematolopica. 1990. 83(3):120-2.

12. Sarnaik $S$ et al. Incidence of cholelithiasis in sickle-cell anemia using the ultra- sonic gray-scale technique. Journal of pediatrics, 1980, 96:1005-8.

13. Gracle WA, Ransohoff DF. The nalual history of silent gallstones: the innocent gallstone is not a myth. New England journal of medicine, 1982, 307:798800 .

14. Walker TM, Serjeant GR. Biliary sludge In sickle-cell disease. Journal of pediatrics, 1996, 129(3):443-5.

15. Ostrow JD, Celic L. Bilirubin chemistry, ionization and solubilization by bile salts. Hepatology, 1984, 4:38S-45S.

16. Risdon RA, Barry M, Flynn DM. Transfusional iron overload: the relationship between tissue iron concentration and hepatic fibrosis in thalassemia. Journal of pathology, 1975, 116:83-95.

17. Iancu $T L$, Neustein HB. Ferritin in human liver cells of homozygous betathalaesemia: ultrastructural observations. British journal of haematology, 1977, 37:527-35.

18. Masera $\mathrm{G}$ et al. Role of chronic hepatitis in development of thalassaemic liver disease. Archives of disease in childhood, 1976, 51:680-5.

19. De Virgiliis $S$, Cornacchia $G$ et al. Chronic liver disease in transtision-dependent thalassaemia: liver iron quantitation and distribution. Acta haematologica, 1981, 65:32-9.

20. Tam SC et al. Growth hormone therapy transiently increases apolipoprotein (a) in short beta-thalassaemia major children with normal growth hormone reserve. Atherosclerosis, 1997, 128(2): 175-82. 